\title{
LARANGAN KEPEMILIKAN TANAH PERTANIAN SECARA ABSENTEE DAN PERTANGGUNG JAWABAN HUKUM BADAN PERTANAHAN DI KABUPATEN TULUNGAGUNG
}

\author{
I Wayan Putra Nugraha, Anak Agung Istri Ari Atu Dewi
}

Fakultas Hukum Universitas Udayana, E-mail: wayanputranugraha11@gmail.com Fakultas Hukum Universitas Udayana, E-mail: ari_atudewi@unud.ac.id

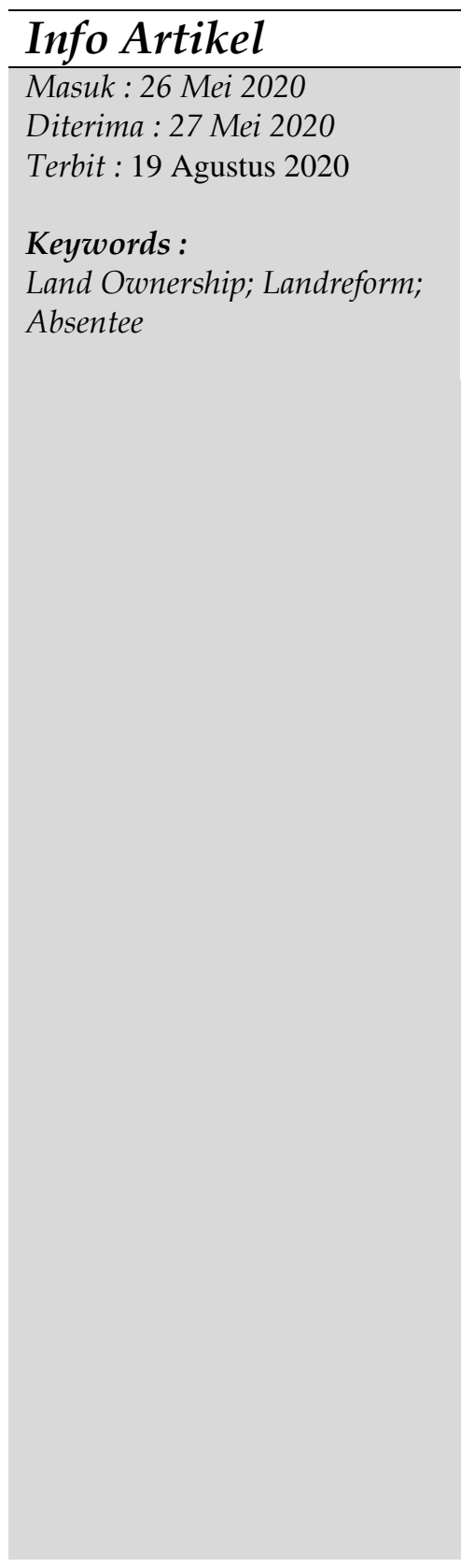

\begin{abstract}
Reforms have been carried out by the government through many land reform programs that regulate land ownership and legal relations between owners and land objects, so that a prosperous and productive society is created to advance the national economy and food security. One of them is the prohibition of agricultural land ownership regulated in article 10 paragraph (1) of the Basic Agrarian Law. It is expected that the owners of agricultural land will work on their own land so that productivity will be maximized, the community will be taught to work and be productive regularly and routinely. But in reality in the field in Jabalsari village Sumbergempol subdistrict Tulungagung regency there are still many people who control agricultural land absentee and interpreted the rules of ownership of agricultural land absentee not yet effective, so this research aims to find out the causes of absentee ownership of agricultural land and how a large role Tulungagung Regency National Land Agency in terms of absentee ownership of agricultural land. This research is carried out using the Empirical Juridical method namely how the law is implemented in social life. The results of research conducted in Jabalsari village Sumbergempol Subdistrict Tulungagung District showed that absentee land ownership in Tulungagung District occurred due to many factors namely: community awareness factors, cultural factors, legal factors, law enforcement factors in the area, facility and infrastructure factors as well as quite a lot It was found that economic factors, and the responsibility of the National Land Agency of Tulungagung Regency still reached the supervision of certified land and improved administration of agricultural land data, this was done so that in the future it would run and orderly administration of the problem of absentee ownership of agricultural land.
\end{abstract}




\author{
Kata kunci: \\ Kepemilikan Tanah; \\ Landreform; Absentee \\ Corresponding Author: \\ I Wayan Putra Nugraha, \\ E-mail: \\ wayanputranugraha11@gmail.com \\ DOI : \\ 10.24843/AC.2020.v05.i02.p10
}

\begin{abstract}
Abstrak
Perombakan banyak dilakukan pemerintah melalui program landreform yang mengatur kepemilikan tanah serta hubungan hukum antara pemilik dengan objek tanah , supaya terciptanya masyarakat yang sejahtera dan produktif untuk memajukan ekonomi nasional dan ketahanan pangan. Salah satunya adalah larangan kepemilikan tanah pertanian yang diatur pada pasal 10 ayat (1) Undang-Undang Dasar Pokok Agraria. Diharapkan para pemilik tanah pertanian akan menggarap tanahnya sendiri supaya produktivitasnya akan lebih maksimal, masyarakat akan diajarkan untuk bekerja dan produktif secara berkala dan rutin. Namun dalam kenyataannya di lapangan di desa jabalsari kecamatan sumbergempol kabupaten Tulungagung masih banyak beberapa orang yang menguasai tanah pertanian secara absentee dan ditafsir peraturan kepemilikan tanah pertanian secara absentee belum berlaku efektif, sehingga penelitian ini bertujuan untuk mengetahui penyebab kepemilikan tanah pertanian secara absentee dan bagaimana peran besar Badan Pertanahan Nasional Kabupaten Tulungagung dalam hal kepemilikan tanah pertanian secara absentee. Penetilitian ini dilaksanakan dengan menggunakan metode Yuridis Empiris yakni bagaimana hukum itu terlaksana di dalam kehidupan bermasyarakat. Hasil penelitian yang dilakukan di desa Jabalsari Kecamatan Sumbergempol Kabupaten Tulungagung menunjukkan bahwa kepemilikan tanah secara absentee di kabupaten Tulungagung terjadi karena banyak faktor yakni : faktor kesadaran masyarakat, faktor budaya, faktor hukum, faktor penegak hukum di daerah, faktor sarana dan prasarana serta yang cukup banyak ditemui yakni faktor ekonomi, dan pertanggung jawaban Badan Pertanahan Nasional Kabupaten Tulungagung masih sampai pada pengawasan tanah yang sudah diserttifikatkan serta perbaikan administrasi pendataan tanah pertanian, hal ini dilakukan supaya kedepannya akan berjalan dan tertib administrasi masalah kepemilikan tanah pertanian secara absentee.
\end{abstract}

\section{Pendahuluan}

Tanah adalah tempat berpijak dan tempat bergantungnya rakyat pada sumber yang sangat besar pada tanah itu sendiri, dengan kata lain tanah adalah sebagai simbol kemakmuran dan kejayaan bagi masyarakat dan menjadi sumber penghidupan yang primer baik dari segi sandang, pangan dan papan. Sehubungan dengan itu beberapa hal harus diberikan kepastian hukum dan perlindungan pada kepemilikan, penyediaan, peruntukan, penguasaan, penggunaan serta bahkan sampai dengan pemeliharaan itu sendiri. Rakyat indonesia sebagian besar bermata pencaharian petani 
maka dengan melestarikan tanah dan memberi perlindungan hukum kepada tanah pertanian juga sebagai tolak ukur dari majunya pertanian dan ekonomi bangsa.

Di samping itu tanah merupakan sumber daya yang penting bagi masyarakat, baik sebagai media tumbuh tanaman, maupun sebagai ruang (space) atau wadah tempat melakukan berbagai kegiatan. Tanah juga merupakan salah satu faktor produksi yang sangat vital bagi kehidupan manusia dan pembangunan suatu bangsa. ${ }^{1}$ Tanah dalam masa pembangunan bertambah penting artinya, karena adanya peningkatan volume pembangunan dalam bidang-bidang pertanian, industri modern, perumahan, kelestarian lingkungan hidup, pengamanan sumber kekayaan alam, kesejahteraan sosial dan lain-lain. Hal ini semakin komplek bila dikaitkan dengan pertambahan penduduk yang memerlukan areal yang luas, otomatis mengakibatkan mengecilnya atau berkurangnya persediaan tanah.

Indonesia telah memiliki ketentuan khusus yang mengatur tentang pertanahan, yaitu dalam Undang-Undang Nomor 5 Tahun 1960 tentang Peraturan Dasar Pokok-pokok Agraria yang biasa disebut UUPA, yang mulai berlaku sejak tanggal 24 September 1960. Usianya yang mencapai 60 tahun, ada lima masalah di bidang pertanahan yang sering mencuat ke permukaan, yaitu "fungsi sosial tanah (Pasal 6), batas maksimum pemilikan tanah (Pasal 7), pemilikan tanah absentee/guntai (Pasal 10), monopoli pemilikan tanah (Pasal 13), dan penetapan ganti rugi tanah untuk kepentingan umum (Pasal 18)". Banyak konflik maupun masalah pertnahan yang sangat pelik karena halhal tersebut diatas bahkan masalah yang berkelanjutan yang tidak mudah diselesaikan. Hal ini sebenarnya bertolak belakang dengan pesatnya perkembangan pembangunan yang sering merupakan dan mengesampingkan banyak hal bahkan unsur keadilan seakan akan sudah tidak ada. Penerapan Pasal 6 UUPA tentang "fungsi sosial tanah, misalnya, masih sering bias dalam praktek di lapangan. Fungsi sosial tanah berarti hak atas tanah apa pun yang ada pada seseorang, tidak dapat dibenarkan tanahnya itu akan dipergunakan (atau tidak dipergunakan) semata-mata untuk kepentingan pribadinya, apalagi kalau hal itu merugikan masyarakat" . ${ }^{2}$

Sementara itu, penerapan Pasal 7 UUPA "tentang batas maksimum pemilikan tanah", dalam kenyataannya juga sering dilanggar. Banyak masalah yang timbul bahkan mengindikasikan kepemilikan tanah yang berlebihan pada beberapa subjek hukum, sedangkan di sisi lain, petani yang kesehariannya bersawah tidak memiliki lahan untuk digarap bahkan menggarap tanah milik orang lain dengan sistem bagi hasil. Pada dasarnya kepemilikan tanah di sebagian besar wilayah tidak merata dan banyak masyarakat yang masih memiliki beberapa lahan yang sangat luas, hal ini menyebabkan ketidak seimbangan terjadi baik secara sosiologis dan ekonomi. Semua ini mengakibatkan petani lapisan paling bawah akan sudah mendapat pekerjaan dan akan menanggung semua akibat kepemilikan tanah yang tidak merata.

Salah satu tujuan yang tercermin pada Undang Undang Dasar Pokok Agraria yang sangat vital adalah landreform, hal ini tidak lain dan tidak bukan sebagai tumpuan, acuan, dan pelindung para petani secara hukum dan akan lebih lanjut akan meningkatkan taraf kesejahteraan petani itu sendiri, dan akan juga berdampak luas

\footnotetext{
${ }^{1}$ Dinalara Dermawati Butarbutar, "Mengatasi Kepemilikan Tanah Absentee/Guntai", Pakuan Law Review, Vol. 1, No. 2, 2015.

2 Boedi Harsono, Hukum Agraria Indonesia, Sejarah Pembentukan Undang-Undang Pokok Agraria, Isi dan Pelaksanaanya, (Jakarta : Djambatan, 2015), hal. 296.
} 
pada ekonomi nasional dan ketahana pangan, hal ini akan sesuai dengan butik-butir Pancasila menuju masyarakat adil dan makmur. ${ }^{3}$

Pengaruh "landreform" dan pertanian secara timbal balik, adalah jelas, karena salah satu tujuan landreform adalah peningkatan produktivitas. Kekwatiran muncul ketika tanah yang sangat luas tidak dibarengi tenaga yang sepadan untuk menggarap tanah, hal ini akan mempengaruhi tingkat produktivitas. akhirnya akan mengakibatkan produktivitas menjadi rendah. Lebih-lebih apabila pemiliknya adalah "absentee landlors" (tuan tanah), yang tanahnya dikerjakan orang lain atau petani penggarap, penggarapan tanah tersebut akan menjadi kurang maksimal karena tidak ada intensifitas khusus pada tanah tersebut bahkan menjadi terkesan digarap seadanya yang sangat kurang produktif, hal ini juga disebabkan tuan tanah biasanya juga sudah memiliki pekerjaan yang mumpuni diluar daerah lokasi tanah yang dimilikinmya, ada juga beberapa tanah yang kosong karena pemiliknya tidak berkenan tanahnya digarap oleh orang lain.

Pelaksanaan pembatasan kepemilikan tanah hingga 52 tahun usia UUPA masih kurang berjalan efisien karena banyak faktor. tampak dari kepemilikan tanah secara absentee/guntai, yang memang sebenarnya diketahui namun sulit untuk dibuktikan karena banyak alasan untuk menghindar dari peraturan. Padahal kepemilikan tanah absentee/guntai ini dalam UUPA dilarangan dengan sangat tegas dan jelas. Larangan ini berkaitan dengan ketentuan-ketentuan pokok landreform yang diatur dalam "Pasal 7,10 dan 17 UUPA". Maksud dari pelarangan pemilikan tanah secara absentee/guntai ini supaya para petani bisa mempunya lahan untuk digarap sendiri dan tidak bergantung dengan orang lain, hal ini secara langsung akan mendukung tumbuh kenbangnya produktivitas secara maksimal dan menambah kesejahteraan hidup petani serta secara tidak langsung mendukung ketahanan pangan nasional.

Sebagai "pelaksanaan Pasal 7 dan Pasal 17 UUPA telah diundangkan Undang-Undang Nomor 56 Prp Tahun 1960 tentang Penetapan Luas Tanah Pertanian. Untuk melaksanakan redistribusi tanah sebagaimana diamanatkan Pasal 17 ayat (3) UUPA jo. Undang-Undang Nomor 56 Prp Tahun 1960 tersebut, telah ditetapkan PP Nomor 224 Tahun 1961 tentang Pelaksanaan Pembagian Tanah dan Pemberian Ganti Kerugian. PP ini kemudian telah diubah dan ditambah dengan PP Nomor 41 Tahun 1964 tentang Perubahan dan Tambahan Peraturan Pemerintah Nomor 224 Tahun 1961 tentang Pelaksanaan Pembagian Tanah dan Pemberian Ganti Kerugian". Pemerintah dalam hal mmemberikan kepastian hukum di bidang pertanahan, maka tanah dapat dipergunakan untuk sebesar-besarnya kemakmuran rakyat, sehingga penguasaan dan pemilikan tanah yang melebihi batas serta tanah absentee/guntai tidak diperbolehkan. Hal ini sesuai dengan "Pasal 3 ayat (1) PP Nomor 224 Tahun 1961 jo. Pasal 1 PP Nomor 41 Tahun 1964 yang menyatakan bahwa pemilikan tanah pertanian oleh orang yang bertempat tinggal di luar kecamatan tempat letak tanahnya dilarang". Berhubung dengan itu ditetapkan, "bahwa pemilik tanah pertanian yang bertempat tinggal di luar kecamatan tempat letak tanahnya tersebut, dalam jangka waktu 6 bulan wajib mengalihkan hak atas tanahnya kepada orang lain di kecamatan tempat letak tanah itu atau pindah ke kecamatan letak tanah tersebut kecuali jarak kecamatannya berbatasan antara pemilik dan tanahnya, sehingga masih dimungkinkan untuk mengerjakan tanah tersebut secara efisien".

\footnotetext{
3 Ef fendi Perangin, Hukum Agraria di Indonesia, Suatu Telaah dari Sudut Pandang Praktisi Hukum, (Jakarta : Rajaw ali, 1986), hal. 122.
} 
Beberapa hal diatas bisa saja diabaikan dan tidak dilaksanakan, hal ini juga akan mengakibatkan tanah yang tidak digarap atau pemiliknya tidak kembali selama aturan tersebut diatas, tanah itu akan dibagikan ke masyarakat sekitarnya. Hal ini sengat perlu diperhatikan terutama oleh para pemilik tanah pertanian, sehingga apabila pemilik pindah akan juga memindahkan hak miliki terhadap tanah tersebut, hal ini sudah dijelaskan secara tegas dalam pasal 10 Undang Undang Dasar Pokok Agraria, yakni :

"(1) Setiap orang dan badan hukum yang mempunyai sesuatu hak atas tanah pertanian pada asasnya diwajibkan mengerjakan atau mengusahakan sendiri secara aktif, dengan mencegah cara-cara pemerasan;

(2) Pelaksanaan dari pada ketentuan ayat (1) akan diatur lebih lanjut dengan peraturan perundangan;

(3) Pengecualian dari pada asas tersebut pada ayat (1) ini diatur dalam peraturan perundangan."

Dalam kenyataannya, sekalipun larangan ini masih berlaku, pemilikan dan/atau penguasaan tanah pertanian secara absentee/guntai, masih banyak dijumpai Pemilik tanah pertanian secara absentee/guntai di desa Jabalsari Kecmatan Sumbergempol Kabupaten Tulungagung, masyarakat yang sebagian besar bermata pencaharian sebagai petani pada desa Jabalsari hanya sebagai penonton bahkan hanya sebagai petani penggarap pada daerahnya sendiri, para pemilik lahan beragama dan sebagian besar adalah orang-orang kota yang bukan merupakan penduduk setempat, yang mendapatkan tanah tersebut melalui jual beli, pewarisan atau cara-cara lainnya, dan penggunaan tanah itu bukan untuk diolah sebagaimana peruntukkan tanahnya tetapi hanya sebagai sarana investasi dan nantinya dijual kembali setelah harganya tinggi. Tanah pertanian di desa Jabalsari masih tetap djadikan obyek spekulasi yang mengakibatkan luas tanah pertanian semakin berkurang karena dialih fungsikan. Sehingga secara yuridis, permasalahan ini terletak pada efektivitas peraturan perundang-undangan yang mengatur program landreform itu sendiri, yang salah satu asasnya adalah larangan pemilikan tanah secara absentee/guntai. Sehingga dapat dikatakan pada Desa Jabalsari khsususnya bahwa gagalnya landreform karena larangan pemilikan tanah secara absentee/guntai yang didasarkan pada batas maksimum tanah pertanian tidak dapat dilaksanakan dengan baik. Sehubungan dengan latar belakang di atas, maka mendorong penulis untuk melakukan kajian bagaimana cara Mengatasi Kepemilikan Tanah Absentee/Guntai pada Desa Jabalsari Kecamatan Sumbergempol Kabupaten Tulungagung dan akan mengangkat rumusan masalah sebagai berikut.

\section{a. RUMUSAN MASALAH}

1. Apa yang menyebabkan terjadinya kepemilikan tanah secara absentee/guntai di kabupaten Tulungagung?

2. Bagaimana cara menagtasi atau menyelesaikan masalah kepemilikan tanahtanah absentee/guntai di Kabupaten Tulungagung dan faktor apa saja yang mempengaruhinya?

\section{b. Tujuan Penulisan}

\section{Tujuan umum}


Memberikan pengetahuan secara mendasar tentang kepemilikan hak atas tanah berbentuk absentee dan memberikan kesadaran pada publik atas pengaturan ini. Dan supaya realisasi dalam kehidupan bermasyarakat berjalan dengan baik.

\section{Tujuan Khusus}

Tujuan penulisan dalam jurnal ini agar masyarakat khususnya di Desa Jabalsari Kecamatan Sumbergempol Kabupaten Tulungagung, sadar akan pengaturan kepemilikan tanah asbsentee dan pemerintah dalam hal ini Badan Pertanahan Nasional Kabupaten Tulungagung lebih tegas dalam menjalankan tugasnya untuk menerapkan pengaturan kepemilikan tanah sesuai Undang-Undang yang berlaku.

\section{Metode Penelitian}

Dalam penulisan jurnal ini, jenis penelitian yang digunakan adalah jenis penelitian yuridis empiris, penelitian berupa studi empiris untuk menemukan teori-teori mengenai proses terjadinya dan mengenai proses bekerjanya hukum di dalam masyarakat. Tipologi penelitian yang terakhir ini sering disebut sebagai Socio Legal Research. ${ }^{4}$ Dengan demikian tidak hanya sebatas mempelajari pasal-pasal perundang-undangan dan pendapat para ahli untuk kemudian diuraikan, tetapi juga menggunakan bahan yang sifatnya empiris dalam rangka mengolah dan menganalisa data-data dari lapangan yang disajikan sebagai pembahasan.

\section{Hasil Dan Pembahasan}

\subsection{Kepemilikan tanah secara absentee/guntai di Kabupaten Tulungagung.}

Penguasaan kepemilikan tanah pertanian diluar batas maksimum luas yang sudah ditentukan oleh salah satu pihak saja menimbulkan masalah tersendiri di dalam kehidupan masyarakat khususnya ini sering terjadi di daerah pedesaan. Pada dasarnya tanah pertani berarti keseluruhan tanah yang berhak dimiliki seluruh orang sekitar objek tanah berada kecuali tanah itu diperuntukkan untuk perumahan, apabila ada tanah pertanian yang sengaja dibanguni atau dibangun tempat tinggal maka masyarakat setempat yang berhak menilai dan menentukan brapa yang bisa menjadi rumah dan sisanya harus dijadikan tanah pertanian dan dimanfaatkan. ${ }^{5}$

Kepemilikan tanah diluar batas maksimum yang sudah ditentukan mengakibatkan tidak meratanya ekonomi dan menciptakan kesenjangan yang sangat tinggi. Hal tersebut menjadikan masyarakat pedesaan khususnya adalah kaum tani masih hidup dalam keadaan yang jauh dari kata layak, padahal dalam "Pasal 9 ayat (2) UUPA menyebutkan, bahwa tiap-tiap Warga Negara Indonesia, baik laki-laki maupun perempuan mempunyai kesempatan yang sama untuk memperoleh sesuatu hak atas tanah untuk mendapat manfaat dan hasilnya, baik bagi diri sendiri maupun

\footnotetext{
4 Bambang Suggono, 1997, Metode Penelitian Hukum, Rajawali Pers, Jakarta, hal. 42.

${ }^{5}$ Boedi Harsono, Hukum Agraria Indonesia, Sejarah Pembentukan Undang-Undang Pokok Agraria, Isi dan Pelaksanaanya, (Jakarta : Djambatan, 2015), hal. 358.
} 
keluarganya".

Dalam menghadapi kesenjangan sosial di kehidupan masyarakat yang khsusnya berprofesi sebagai petani kehidupan yang jauh dari kata layak bahkan sangat sulit karena biaya hidup mecakup bahan makanan dan biaya pendidikan anak yang makin tahun makin melonjak tinggi. Faktor yang sangat berpengaruh terhadap besarnya produksi padi adalah luas panen dan produktivitas, selain itu ada faktor lain yang sifatnya sangat mendasar adalah kesediaan lahan pertanian, ${ }^{6}$ Disini adanya tidak keberdayaan petani dalam bertahan dengan profesi yang telah ditekuninya selama ini, sehingga untuk bertahan dan melanjutkan hidup petani banyak yang menjual tanahnya pada orang-orang yang lebih mampu. Selain kehilangan profesi mereka, petani juga tidak mempunyai sawah untuk digarap lagi sehingga mereka bergantung pada tanah sawah yang diimiliki orang lain. Para petani akan mengerjakan tanah milik orang lain dan akan membagi hasilnya dengan orang yang memiliki sawah tersebut, petani yang sepertinya ini biasanya disebut dengan petani penggarap. ${ }^{7}$

Pemerinah sangat peduli dengan keadaan diatas bahkan pemerintah sangat menyoroti masalah ini dan akhirnya terbentuk dan terciptanya kebijakan landreform di Indonesia. Landreform berarti berubahnya sistem kepemilikan dan penguasaan tanah yang melampaui batas luas maksimal diubah dengan sistem tata pertanahan seiring dengan perubahan dan perkembangan masyarakat yang belomba lomba membangun ekonomi dalam kehidupan.

Berkenaan dengan masalah diatas UUPA menciptakan asas yang menghapus pihakpihak yang menguasasi tanah dibatas luas maksimal yang sudah ditentukan Pasal 7 UUPA yang menetapkan bahwa "untuk tidak mengurangi kepentingan umum, maka pemilikan dan penguasaan tanah yang melampaui batas tidak diperkenankan." Asas ini juga menyebabkan dan timbul fungsi sosial antara pemilik tanah satu dengan pemilik tanah yang lain, dalam UUPA juga mengatur tentang asas yang berisi berapa luas maksimal yang bisa dimiliki oleh seseorang yang terdapat dalam Pasal 17 UUPA. Pembatasan pemilikan untuk Badan Hukum ditentukan berdasarkan keputusan pemberian haknya. Peraturan pemerintah nomor 24 Tahun 1961 yang tambahan dan perubahannya terdapat pada peraturan pemerintah Nomor 41 Tahun 1964 Tentang Pelaksanaan Pembagian Tanah Dan Ganti Kerugian, pada pasal 3 ayat 1 Peraturan Pemerintah Nomor 224 tahun 1961 Tentang Pelaksanaan pembagian Tanah Dan Ganti Kerugian, menyebutkan bahwa: "Pemilik tanah yang bertempat tinggal diluar kecamatan tempat letak tanahnya, dalamjangka waktu 6 bulan wajib mengalihkan hak atas tanahnya kepada orang lain dikecamatan tempat letak tanah itu atau pindah ke kecamatan letak tanah tersebut". ${ }^{8}$

Pelaksanaan asas dalam "Pasal 10 UUPA tersebut maka pemerintah melalui Peratuan Pemerintah Nomor 224 Tahun 1961 Tentang Pelaksanaan Pembagian Tanah dan Pemberian Ganti Kerugian telah menyebutkan secara khusus larangan kepemilikan tanah pertanian secara absentee." Dalam Pasal 3 PP 224 Tahun 1961 menyebutkan

\footnotetext{
${ }^{6}$ Ardiansyah Al Ghani, "Kebijakan Penyelesaian Tanah "Absentee/Guntai" Di Kabupaten Boyolali Berdasarkan Undang-Undang Nomor 56 PRP Tahun 1960 Tentang Penetapan Luas Tanah Pertanian", Repertorium Jurnal Pemikiran \& Penelitian Bidang Keperdataan dan Kenotariatan Kenotariatan, Vol. 5, No. 1, 2018.

7 Chandra Dewangga Marditya Putra, "Penerapan Larangan Pemilikan Tanah Pertanian Secara Absentee", Jurnal Hukum \& Kenotariatan, Vol. 3, No. 2, 2019.

${ }^{8}$ Abdurahman, Sultan, "Tinjauan Yuridis Kepemilikan Tanah Absentee Dikaji dari Undangundang Nomor 5 Tahun 1960 Tentang Peraturan Dasar Pokok Agraria." Lex Crimen, vol. 5, no. 6, 2016.
} 
bahwa: ${ }^{9}$

"Ayat (1) Pemilik tanah yang bertempat tinggal diluar kecamatan tempat letak tanahnya, dalam jangka waktu 6 bulan wajib mengalihkan hak atas tanahnya kepada orang lain di kecamatan tempat letak tanah itu atau pindah ke kecamatan letak tanah tersebut.

Ayat (2)Kewajiban tersebut pada ayat 1 pasal ini tidak berlaku bagi pemilik tanah yang bertempat tinggal di kecamatan yang berbatasan dengan kecamatan tempat letak tanah, jika jarak antara tempat tinggal pemilik dan tanahnya masih memungkinkan mengerjakan tanah itu secara effisien, menurut pertimbangan Panitia Landreform Daerah Tingkat II;

Ayat (3) Dengan tidak mengurangi ketentuan tersebut pada ayat 2 pasal ini, maka jika pemilik tanah berpindah tempat atau meninggalkan tempat kediamannya keluar kecamatan tempat letak tanah itu selama 2 tahun berturut-turut, ia wajib memindahkan hak miliktanahnya kepada orang lain yang bertempat tinggal di kecamatan itu;

Ayat (4) Ketentuan dalam ayat 1 dan 3 pasal ini tidak berlaku bagi mereka, yang mempunyai tanah dikecamatan tempat tinggalnya atau dikecamatan sebagai yang dimaksudkan dalam ayat 2 pasal ini, yang sedang menjalankan tugas Negara, menunaikan kewajiban agama, atau mempunyai alasan khusus lainnya yang dapat diterima oleh Menteri Agraria. Bagi pegawai-pegawai negeri dan pejabat-pejabat militer serta yang dipersamakan dengan mereka, yang sedang menjalankan tugas Negara, perkecualian tersebut pada ayat ini terbatas pada pemilikan tanah pertanian sampai seluas $2 / 5$ dari luas maksimum yang ditentukan untuk daerah yang bersangkutan menurut Undang-undang Nomor 56 Prp Tahun 1960".

Dalam pelaksanaan Peraturan Pemerintah Nomor 224 Tahun 1961 telah dianggap kurang sempurna, maka pemerintah melakukan Perubahan dan penambahanterhadap PP 224 Tahun 1961 Tentang Pelaksanaan Pembagian Tanah dan Pemeberian Ganti Kerugian yang tertuang dalam Peraturan Pemerintah Nomor 41 Tahun 1964 Tentang Perubahan Dan Tambahan Peraturan Pemerintah Nomor 224 Tahun 1961 Tentang Pelaksanaan Pembagian Tanah Dan Pemberian Ganti Kerugian. Dalam Pasal 3 PP 41 Tahun 1964 ditambahkan sebagai berikut:

Pasal 3a. Ayat (1) Pemilik tanah pertanian yang berpindah tempat atau meninggalkan tempat kediamannya keluar Kecamatan tempat letak tanah itu selama 2 (dua) tahun berturut-turut, sedang ia melaporkan kepada pejabat setempat yang berwenang, maka dalam waktu 1 (satu) tahun terhitung sejak berakhirnya jangka waktu 2 (dua) tahun tersebut di atas ia diwajibkan untuk memindahkan hak milik atas tanahnya kepada orang lain yang bertempat tinggal di Kecamatan letak tanah itu";

Ayat (2) Jika pemilik tanah yang dimaksudkan pada ayat (1) pasal ini berpindah tempat atau meninggalkan tempat kediamannya keluar Kecamatan tempat letak tanah itu, sedang ia tidak melaporkan kepada pejabat setempat yang berwenang, maka dalam waktu 2 (dua) tahun terhitung sejak ia meninggalkan tempat kediamannya itu diwajibkan untuk memindahkan hak milik atas tanahnya kepada orang lain yang bertempat tinggal di Kecamatan letak tanah itu";

Pasal 3b. Ayat (1) Pegawai Negeri dan Anggota Angkatan Bersenjata serta orang lain yang dipersamakan dengan mereka, yang telah berhenti dalam menjalankan tugas Negara dan yang mempunyai hak atas tanah pertanian di luar Kecamatan tempat

9 Elfira Permatasari, Habib Adjie dan Hardianto Djanggih, "Perlindungan Hukum Kepemilikan Tanah Absentee yang diperoleh Akibat Pewarisan", Varia Justicia, Vol. 14, No. 1, 2018. 
tinggalnya dalam waktu 1 (satu) tahun terhitung sejak ia mengakhiri tugasnya tersebut diwajibkan pindah ke Kecamatan letak tanah itu atau memindahkan hak milik atas tanahnya kepada orang lain yang bertempat tinggal di Kecamatan di mana tanah itu terletak";

Ayat (2) Dalam hal-hal tertentu yang dapat dianggap mempunyai alasan yang wajar, jangka waktu tersebut dalam ayat (1) di atas dapat diperpanjang oleh Menteri Agraria. Pasal 3c. (1) Jika seseorang memiliki hak atas tanah pertanian di luar Kecamatan di mana ia bertempat tinggal, yang diperolehnya dari warisan, maka dalam waktu 1 (satu) tahun terhitung sejak si pewaris meninggal diwajibkan untuk memindahkannya kepada orang lain yang bertempat tinggal di Kecamatan di mana tanah itu terletak atau pindah ke Kecamatan letak tanah itu";

Ayat (2) Dalam hal-hal tertentu yang dapat dianggap mempunyai alasan yang wajar jangka waktu tersebut dalam ayat (1) di atas dapat diperpanjang oleh Menteri Agraria";

Pasal 3d. Dilarang untuk melakukan semua bentuk pemindahan hak baru atas tanah pertanian yang mengakibatkan pemilik tanah yang bersangkutan memiliki bidang tanah di luar Kecamatan di mana ia bertempat tinggal";

Pasal 3e. Tidak dipenuhinya ketentuan-ketentuan tersebut dalam pasal- pasal 3a, 3b, 3c dan 3d mengakibatkan baik tanah maupun pemilik tanah yang bersangkutan dikenakan ketentuan-ketentuan tersebut dalam pasal 3 ayat (5) dan (6) Peraturan Pemerintah No. 224 tahun 1961 (Lembaran-Negara tahun 1961 No. 280)".

Peraturan tersebut memiliki esensi dan urgensi sangat tegas bahwa tidak diperbolehkan memiliki tanah secara absentee, karena menyebabkan hal-hal yang tidak terduga seperti pemerasan dan kerja paksa mungkin pada petani yang tidak memiliki sawah seperti pada jaman penjajahan sebelum Indonesia merdeka.

Sesuai dengan penelitian di lapangan dilakukan di Desa Jabalsari sebagai desa yang sebagian besar $61 \%$ (enam puluh satu persen) berprofesi sebagai petani dan dalam hal ini ada beberapa kepemilikan absentee. Kepemilikkan tanah pertanian di desa jabalsari beberapa dikuasasi oleh pihak diluar Kecamatan sumbergempol Desa Jabalsari bahkan sampai dengan orang diluar Kabupaten Tulungagung. Dari keterangan Bapak Mahmudi kepala Desa Jabalsari kepemilikan tanah secara absentee di Desa Jabalsari dikarenakan adanya perbuatan hukum yakni jual beli dan juga pewarisan, hampir seluruh kejadia ini didukung karena keperluan uang para penjualnya. Banyak tanah yang belum diurus sampai dengan berbentuk seritikat sehingga dalam bentuk SPPT PBB tanah ini bisa diperjual belikan secara dibawah tangan disaksikan oleh Kepala Desa dan perangkat Desa Jabalsari, sama halnya dengan pewarisan biasanya dilakukan pembagian warisnya dikantor desa cukup disaksikan oleh kepala Desa dan disaksikan oleh perangkat Desa setempat. Hal ini disebabkan karena pengetahuan hukum bagaimana tatacara administrasi yang benar kurang dipahami oleh masyarakat dan banyak faktor lainnya. ${ }^{10}$

Sangat banyak tanah di Desa Jabalsari yang belum bersertifikat dan susah dilacak dengan badan kantor pertnahan setempat, tanah ini kebanyakan masih berbentuk SPPT PBB dan yang lama masih bebentuk petuk yang biasanya disebut dengan "Tumpi". Hal ini tersebut juga salah satu kemudahan bagi para pembeli untuk memiliki atatu menguasai tanah tersebut walaupun pembeli adalah oranng yang datang dari luar daeraah desa Jabalsari. Dilansir dari wawancara dengan bapak

${ }^{10}$ Mahmudi,wawancara, selaku kepala desa Jabalsari Kabupaten Tulungagung pada tanggal 10 Januari 2020 . 
Selamet warga Desa gamping Kecamatan Campurdarat Kabupaten Tulungagung, pemilik tanah pertanian yang Absentee seluas 1200 M2 di Rukun Tetangga 06 Rukun Warga 01 yang berada di desa Jabalsari, ${ }^{11}$ kepemilikan dan proses dalam pengalihan hak atas tanah pertanian ini dilakukan dengan alasan:

a. Kebiasaan masyarakat di desa Jabalsari sangatlah mudah dijangkau yakni peralihan hak atas tanah secara dibawah tangan.

b. Untuk proses peralihan hak secara dibawah tangan sangatlah murah dan tidak memerlukan syarat yang banyak dan rumit, hal ini juga dibenarkan oleh bapak Mahmudi kepala desa Jabalsari

c. Dan proses yang dilakukan sangat cepat dan sangat sederhana.

Dari keterangan Bapak Mahmudi kepala Desa Jabalsari, peralihan tanah secara dibawah tanganm ini sebagian besar dilakukan oleh penjual dan pembeli yang ada hubungan kerabat dan di situasi lain biasanya walaupum dari daerah luar pembeli sangat dikenal oleh warga setempat, berkaitan dengan domisili yang berasal dari luar daerah pemerintah Desa Jabalsari tidak bisa melarang dikarenakan prose peralihan tanah secara jual beli ini adalah perbuatan yang sangat private tergantung kesepakatan masing-masing pihak, maka setelah terjadi kata sepakat antara penjual dan pembeli proses peralihan tanah ini akan dilangsungkan. ${ }^{12}$

Bapak Mahmudi juga memberikan keterangan terhadap tanah pertanian yang sudah dalam sertifikat hak milik (SHM), karena calon pembeli yang akan membeli tanah tersebut diharuskan memiliki KTP di desa Jabalsari walaupun ini juga demi kepentingan yang singkat dalam proses jual beli tanah ini, dan setelah selesai melakukan jual beli, maka pihak pembeli akan kembali pada domisili asalnya, dengan ini pihak desa Jabalsari akan berkoordinasi langsung dengan Badan Pertanahan Nasional setempat sehingga bisa berlangsung jual beli yang sah.

Hal tersebut diatas berkaitan dengan pengawasan dan pengecekkan secara langsung yang dilakukan oleh Badan Pertanahan Naisonal Kabupaten Tulungagung pada tanah yang sudah bersertifikat yang masih bisa dijangkau karena adanya data pada buku tanah yang beradap di BPN Kabupaten Tulungagung, beda halnya dengan tanah yang belum bersertifikat yang keberadaannya dan kepemilikannya kadang susah dijangkau karena tidak adanya koordinasi desa kepada BPN Kabupaten Tulungagung.

Tidak semua peralihan tanah yang dilakukan secara jual beli terdaftar di Kantor Pertanahan Nasional khususnya tanah-tanah yang tidak bersertifikat sehingga pemerintah juga sulit melacak jejak tanah tersebut dan menjalankan sebgaian daroi kebijakan andreform yang diatur dalam peraturan perundang-undangan, salah satu kewenagan pemerintah dalam hal ini adalah kepemilikan tanah pertanian yang pemilikinya adalah diluar kecmatan diluar letak objek tanah tersebut disebut dengan absentee. Peralihan secara jual beli dibawah tangan tidak diperkenankan karena sebgaian besar ada maksud tertentu dalam proses itu sehingga dalam melanggar peraturan Undang-undang.

Pada peralihan tanah yang tidak berbentuk sertifikat dan juga calon pembelinya ada dari luar daerah prosesnya akan susah di data dan dilacak oleh Badan Pertanahan Nasinoal, karena tidak adanya kerjasama yang baik antara pihak desa dengan Badan

11 Selamet, Wawancara, pemilik tanah pertanian absentee di Desa Jabalsari kabupaten Tulunggagung, pada tanggal 11 Januari 2020.

12 Mahmudi,wawancara, selaku kepala desa Jabalsari Kabupaten Tulungagung pada tanggal 10 Januari 2020 . 
Pertanahan Nasional Kabupaten Tulungagung, beda halnya dengan tanah yang sudah bersertifikat akan mudah dilacak karena sudah terdata di kantor BPN setempat dan akan mengecek seluruh data penjual dan pembeli sebelum melakukan jual beli apabila syarat tidak memenuhi sesuai peraturan yang berlaku maka proses peralihan tanah secara jual beli tidak bisa dilangsungkan dan akan dikaji ulang, dilihat dari dua pandangan diatas sebenarnya asas yang mengatur adanya kepemilikan tanah secara absentee sudah dijalankan namun masih belum efektif dilihat dari situasi di lapangan. Bapak Mahmudi menambahkans sedikit keterangan karena selama ini tanah pertanian yang dikuasai oleh pihak luar juga tidak ada masalah dalam hal ini warga setempat boleh menggarap tanahnya sebagai petani penggarap, dilihat dari sini juga tidak ada faktor yang sangat kuat untuk menhentikan aktivitas jual beli tanah pertanian karena juga menurt beliau dengan adanya jual beli ini adalah sismbiosis mutualisme sejauh tidak ada masalah ke depan dan tanahnya masih produktif digarap petani penggarap dengan sistem yang sangat adil yakni sistem bagi hasil. ${ }^{13}$

Boedi harsono berpendapat bahwa sistem bagi hasil adalah sistem dimana seseorang atau badan hukum melaksanakan kegiatan bercocok tanam pada lahan pertanian tertentu dan akan disebut dengan penggarap, namun sudah jelas tanah yang dipakai untuk kegiatan diatas adalah tanah yang kepemilikannya dari pihak lain. Perjanjian bagi hasil sendiri akan berlangsung setelah adanya kata kesepakatan dari para pihak yang bersangkutan terutama intinya pembagian hasil dari kegiatan yang dilakukan oleh penggarap pada lahan yang disediakan oleh pemilik lahan. ${ }^{14}$

Menurut Undang-Undang nomor 2 Tahun 1960 yang dimaksud perjanjian bagi hasil adalah "perjanjian bagi hasil,ialah perjanjian dengan nama apapun juga yang diadakan antara pemilik pada satu pihak dan seseorang atau badan hukum pada lain pihak yang dalam undang-undang ini disebut"penggarap" "berdasarkan perjanjian mana penggarap diperkenankan oleh pemilik tersebut untuk menyelenggarakan usaha pertanian di atas tanah pemilik, dengan pembagian hasilnya antara kedua belah pihak"

Pada kenyataannya di lapangan perjanjian bagi hasil sebenarnya sangat tidak menguntungkan bagi petani pasalnya perjanjian ini dilakukan sebagian besar dengan secara lisan ada segelintir yang dibuat dengan perjanjian namun dalam isi perjanjian itu tidak ada kepastian dalam hal brapa lama petani penggarap bisa menggarap tanah yang tersebut, maka sewaktu-waktu pemilik memerlukan tanahnya, pemilik akan mengambil tanahnya untuk keperluannya sendiri hal ini sangat jauh dari harapan dari asas Absentee yang sangat diharapkan melindungi para petani.

Dilansir dari keterangan bapak Jamal sangat miris dalam hasil perjanjian bagi hasil bahkan petani harus memberikan sebagian hasil berish pada pemilik tanah sedangkan modal untuk bercocok tanam mulai dari bibit, pengairan dan pupuk ditanggung oleh petani sendiri. Hal yang disayangkan apabila terjadi gagal panen petani akan menanggung resikonya sendiri tanpa bantuan dari pemilik tanah, hal ini menggambarkan seberapa tidak adanya keadilan dan perlindungan terhadap petani. ${ }^{15}$ Beliau menambahkan bahwa peraturan ini akan efektif apabila petani yang memiliki

${ }_{13}$ Mahmudi,wawancara, selaku kepala desa Jabalsari Kabupaten Tulungagung pada tanggal 10 Januari 2020 .

14 Boedi Harsono, Hukum Agraria Indonesia, Sejarah Pembentukan Undang-Undang Pokok Agraria, Isi dan Pelaksanaanya, (Jakarta : Djambatan, 2015), hal. 398.

${ }^{15}$ Jamal, Wawancara, selaku Petani Penggarap tanah Absentee di desa Jabalsari pada tanggal 13 Januari 2020. 
tanahnya sendiri dan bisa mengelolanya dengan sangat maksimal sehingga mendapat hasil produktivitas yang masimal juga dan dengan secara berkala akan trus berjalan produktivitasnya karena tidak perlu takut lahannya hilang atau diambil paksa oleh orang lain. Dalam aturannya seharusnya yang dapat membeli tanah pertanian adalah yang profesinya sebagai petani sehingga tidak memutus matai rantai produktivitas pertanian, kurang lebih seperti itu.

\subsection{Penyelesaian masalah kepemilikan tanah-tanah absentee/guntai di Kabupaten Tulungagung dan faktor yang mempengaruhinya.}

Kebijakan Landerform bertujuan untuk menjauhkan traumatis sisa jaman penjajahan Belanda,trauma yang dimaksudkan adalah adanya kerja paksa dan penguasaan lahan yang berlebihan pada masa itu khususnya hal ini sangat menguntungkan para petani karena aturan ini akan mengawal kesejahteraan petani secara langsung dan pada sektor luas akan menciptakan ekonomi dan ketahanan pangan nasional yang sangat kuat sehingga terciptannya masyarakat yang adil dan makmur sesuai dengan amanat dari Pancasila. Untuk mencapai itu semua "Tujuan Landerform yakni :

1. "Untuk mengadakan pembagian yang adil atas sumber penghidupan rakyat tani yang berupa tanah, dengan maksud agar ada pembagian hasil yang adil pula, dengan merombak struktur pertanahan sama sekali secara revolusioner, guna merealisir keadilan sosial.

2. Untuk melaksanakan prinsip tanah untuk tani, agar tidak terjadi lagi tanah sebagai obyek spekulasi dan alat pemerasan.

3. Untuk memperkuat dan memperluas hak milik atas tanah bagi setiap warga negara Indonesia yang berfungsi sosial"

4. Untuk mengakhiri sistem tuan tanah dan menghapuskan pemilikan dan penguasaan tanah secara besar-besaran dengan tak terbatas, dengan menyelenggarakan batas maksimum dan batas minimum untuk tiap keluarga. Dengan demikian mengikis pula sistem liberalisme dan kapitalime atas tanah dan memberikan perlindungan terhadap golongan ekonomis yang lemah.

5. Untuk mempertinggi produksi nasional dan mendorong terselenggaranya pertanian yang intensif secara gotong-royong dalam bentuk koperasi dan bentuk gotong-royong lainnya." 16

harus segera dilaksanakan secara efektif sehingga terdapat kepastian hukum dan menjamin taraf hidup masyarakat khususnya para petani.

Kebijakan Landerform ini sangat jelas akan memberingan perlindungan dan kepastian hukum pada para pemilik tanah pertanian tersebut karena apabila tanah tersebut diambil negarapun, para pihak pemilik tanah itu akan diberikan ganti rugi oleh pemerintah, namun hal ini tidak sesuai perkembangan masyarakat dan kenyataan yang ada di lapangan karena ada beberapa faktor termasuk salah satunya bertumbuhan jumlah masyrakat yang sangat pesat sedangkan lahan pertanian yang sedikit dan biaya hidup yang semakin meningkat banyak orang terpaksa menjual tanahnya dengan cara apapun untuk bertahan hidup. Tanah-tanah yang menjadi objek landerfrom meliputi: ${ }^{17}$

\footnotetext{
${ }^{16}$ Ibid. Hal. 5.

17 Pasal 1, Peraturan Pemerintah Nomor 224 Tahun 1961 tentang Pelaksanaan Pembagian Tanah dan Pemberian ganti Kerugian.
} 
1. “Tanah-tanah yang melebihi batas maksimum dan tanah-tanah yang jatuh pada Negara;

2. Tanah-tanah yang pemiliknya bertempat tinggal diluar daerah sehingga membuat penguasaan tanahnya dinilai tidak ekonomis, menimbulkan sistem penghisapan, dan juga ditelantarkan, oleh karena peraturan perundang-undangan tanahnya diambil oleh Pemerintah;

3. Tanah-tanah milik Swapraja dan bekas Swapraja yang telah beralih kepada Negara;

4. Tanah-tanah dikuasai langsung oleh Negara selain yang telah disebut diatas, seperti tanah partikiler, tanah-tanah Hak Guna Usaha yang telah berakhir masa waktunya, dan tanah-tanah lain tetapi tidak termasuk di dalamnya tanah wakaf dan tanah untuk peribadatan."

Undang-Undang Nomor 5 Tahun 1960 tentang Peraturan Dasar Pokok-Pokok Agraria dibuat dengan landasan bahwa masyarakat akan dijamin kepastian hukumnya dan menuju kearah keadilan dalam berbagai permasalahan yang berhubungan dengan tanah, karena pada dasarnya seluruh masyarakat pasti berhubungan dengan kepemilikan, penggunaan, pemanfaatan dan menjalani kehidupan bahkan bergantung dengan tanah. dalam pasal 19 ayat (1) Undang-Undang Pokok Agraria adalah pasal yang dimana isinya memberikan jaminan kepastian hukum, terhadap masyarakat menyebutkan bahwa "Untuk Menjamin kepastian hukum hak atas tanah oleh Pemerintah diadakan pendaftaran tanah diseluruh wilayah Republik Indonesia menurut ketentuan yang diatur dengan Peraturan Pemerintah".

Indonesia dengan beragama suku dan budaya serta kondisi masing-masing daerah maka dicanangkannya Agrarian reform (Panca Program). ${ }^{18} 5$ program ini adalah acuan dan sebagai strategi pemerintah untuk menuju masyarakat yang terjamin kepastian hukumnya dalam hal pertanahan dan bahkan menuju kemakmuran dan keadilan berdasarkan pancasila.

Peraturan dalam pasal 10 UUPA mengatakan "bahwa tanah pertanian wajib dikerjakan sendiri oleh pemiliknya sehingga muncul ketentuan yang namanya Absentee". Kata Absentee berasal dari Bahasa inggris yang berarti yang tidak ada atau yang tidak hadir ditempatnya. ${ }^{19}$ Dalam pelarangan kepemilkan tanah juga terdapat pada "Peraturan Menteri Agraria Dan Tata Ruang/ Kepala Badan Pertanahan Nasional Nomor 18 Tahun 2016 Tentang Pengendalian Penguasaan Tanah Pertanian

18 Panca Program Agrarian Reform:

1. "Pembaharuan hukum agraria, melalui unifikasi hukum yang berkonsepsi nasional dan pemberian jaminan kepastian hukum;

2. Penghapusan hak-hak asing dan konsesi-konsesi kolonial atas tanah;

3. Mengakhiri penghisapan feodal secara berangsur-angsur;

4. Perombakan pemilikan dan penguasaan tanah serta hubungan-hubungan hukum yang bersangkutan dengan penguasaan tanah dalam mewujudkan pemerataan kemakmuran dan keadilan;

5. Perencanaan persediaan dan peruntukan bumi, air dan kekayaan alam yang terkandung di dalamnya serta penggunaanya secara terencana, sesuai dengan daya dukung dan kemampuannya."

1910 Echols, Jhon M dan Hassain Sadhily, Kamus Inggris-Indonesia (an English-Indonesian Dictionary), (Jakarta: Gramedia, 2012), hlm. 4. 
menyebutkan larangan pemilikan tanah absentee yang terdapat padal pasal 7 ayat (1) dengan ketentuan sebagai berikut":

Pemilik tanah pertanian yang bertempat tinggal di luar kecamatan tempat letak tanah dalam waktu 6 (enam) bulan sejak tanggal perolehan hak", diharuskan untuk :

a. mengalihkan hak atas tanahnya kepada pihak lain yangberdomisili di kecamatan tempat letak tanah tersebut; atau

b. pindah ke kecamatan letak tanah tersebut." 20

Larangan dari pemilikan tanah Absentee tentunya mempunyai tujuan. Hal ini dikemukakan oleh Boedi Harsono, yang mengatakan "tujuan adanya larangan ini untuk memberikan hasil dari tanah pertanian untuk sebagian besar dapat dinikmati oleh masyarakat pedesaan tempat letak tanah pertanian, karena dengan pemilik tanah bertempat tinggal di daerah tanah tersebut maka hasil dari tanah pertanian itu lebih maksimal." 21 "Pasal 2 ayat (1) Peraturan Menteri Agraria Dan Tata Ruang/ Kepala Badan Pertanahan Nasional Nomor 18 Tahun 2016 Tentang Pengendalian Penguasaan Tanah Pertanian juga menyebutkan Maksud dan tujuan adanya larangan pemilikan tanah pertanian secara absentee yaitu "untuk mengurangi kesenjangan sosial, memeratakan kesejahteraan masyarakat dan menjamin ketahanan pangan." 22

Larangan pemilikan tanah secara Absentee "tidak berlaku bagi pemilik tanah yang tempat tinggalnya berbatasan langsung dengan kecamatan tempat letak tanah pertaniannya, dengan syarat jarak tempat pemilik tanah pertanian itu masih memungkinkannya untuk dapat mengerjakan tanah pertaniannya dengan baik danefisien." 23 Ketentuan dalam pasal 10 UUPA ini secara yuridis merupakan "Dwingend Recht" atau sifatnya memaksa karena menyangkut kepentingan umum.

Larangan Pemilikan Tanah Pertanian secara Absentee dimuat secara tegas oleh UUPA yang berkaitan dengan ketentuan-ketentuan Landerfrom yang diatur dalam Pasal 7, Pasal 10, Pasal 17 UUPA. Pasal 7 UUPA berbunyi "Untuk tidak merugikan kepentingan umum maka pemilikan dan penguasaan tanah yang melampaui batas tidak diperkenankan". Maksud dari pasal ini 11 yaitu untuk mencegah terjadinya pemilikan tanah yang melampaui batas dari hak perorangan.

Berdasarkan penelitian di lapangan tepatnya di desa Jabalsari kecamatan sumbergempol Kabupaten Tulungagung terdapat banyak pemilikan tanah pertanian secara absentee dengan bukti kepemilikan yang sah yakni Sertifikat Hak Milik, peraturan pemilikkan tanah pertanian secara absentee berlaku kurang efektif karena banyak faktor dan penyebab, beberapa faktor yakni :

1. Faktor dimana masyarakat yang tidak melaksanakan peraturan yang sudah ada dan bahkan bukan tidak melaksanakan, masyarakat sebagian besar tidak tahu dengan adanya peraturan larangan kepemilikan tanah pertanian secara absentee, peraturan sudah disusun dengan baik dan tegas supaya terciptanya kehidupan masyarakat yang tertib dan damai. Beberapa

$20 \quad$ Pasal 7 ayat (1), Peraturan Menteri Agraria Dan Tata Ruang/ Kepala Badan Pertanahan Nasional Nomor 18 Tahun 2016 tentang Pengendalian Penguasaan Tanah Pertanian.

${ }_{21}$ Boedi Harsono, Hukum Agraria Nasional (sejarah pembentukan undang-undang pokok agrarian, isi dan pelaksanaanya), (Jakarta: Jambatan, 2008), hlm. 385.

22 Pasal 2 ayat (1), Peraturan Menteri Agraria dan tata ruang/Kepala Badan Pertanahan Nasional Nomor 18 Tahun 2016 tentang Pengendalian Penguasaan Tanag Pertanian.

23 Pasal 10, Undang-Undang Nomor 5 Tahun 1960 tentang Peraturan Dasar Pokok-pokok Agraria. 
kesadaran hukum yang harus diketahui masyarakat yakni meliputi : Pengetahuan, Pemahaman, Sikap dan Perilaku hukum.

2. Faktor Budaya, dalam hal ini yang melekat pada faktor yakni adalah pewarisan, setiap keluarga pasti akan mengalami peristiwa hukum ini karena peristiwa ini terkadang munculnya secara mendadak, bahkan kita tidak bisa mengatur bahwa ahli warisnya harus juga bertempat tinggal pada desa dimana letak objek tanah berada, seharusnya para ahli waris harus berdomisili dimana objek tanah itu berada, hal ini supaya tidak terjadi kepemilikan tanah secara absentee dan seharusnya atau dengan cara lain ahli waris harus merelakan tanahnya pada warga setempat. Hal ini berhubungan dengan konsep landform yang bertujuan untuk menjaga tanah pertanian demi penghidupan para petani di sekitarnya, apabila tanah pertanian dikuasasi oleh masyarakat yang bukan berprofesi sebagai petani, kebanyakan atau sebagian besar tanah akan terlantar dan tidak menghasilkan apa-apa.

3. Faktor Hukum, dalam hal ini tertinggalnya produk hukum yang sudah dibuat dari tahun 1960an yang dasarnya ada pada Undang-undang Dasar Pokok Agraria pada pasal 10, mengapa dikatakan tertinggal karena hukum ini diciptakan untuk dipatuhi dan mengatur tatanan kehidupan bermasyarakat, namun masyarakat sangat pesat berkembang saat ini, hukum yang sudah dibuat pada tahun itu mungkin sudah sesuai dengan situasi dan kondisi pada jaman sekarang.

4. Faktor Sarana dan Prasarana, disini merujuk pada laporan dari aparat pedesaan kepada Badan Pertanahan Nasional Kabupaten Tulungagung yang akan berpengaruh pada data yang terkumpul tidak sesuai dengan apa yang ada pada lapangan, sesuai dengan keterangan kepala kantor Kabupaten Tulungagung, Bapak Eko Jauhari. ${ }^{24}$ Dalam hal ini para aparat pemerintah dari desa setempat bahkan pihak BPN kurang komunikasi dengan baik. Bapak Eko Jauhari menambahkan bahwa walaupun adaalat pendeteksi yang terhubungan dengan satelit namun secara berkala alat ini juga harus didukung dengan kepengurusan terhadap tanahnya masing supaya BPN mempunyai data dan dapat diketahui letak objek tanah yang bersangkutan.

5. Faktor Aparat dan Penegak Hukum, Seperti dilansir dari keterangan Bapak Eko Jauhari, ${ }^{25}$ kepalada desa tidak mempunyai tanggung jawab melaporkan kepada pihak Badan Pertanahan setempat apabila ada peralihan hak milik atas tanah kshsusnya tanah pertanian karena sudah menjadi kebiasaan yang sukar dirubah di Kecamatan Sumbergempol. Sehubungan dengan peristiwa diatas banyak tanah yang dimilki secara absentee yang tidak diketahui dan tidak terdeteksi adanya dan bahkan beberapa aparat desa mengaku tidak tau dengan adanya aturan kepemilikan tanah pertanian yang pemiliknya tinggal diluar kecamatan itu tidak diperbolehkan, hal ini juga karena kurangnya sosialisasi yang berkala dan menyeluruh meliputi semua desa di kabupaten tulungagung.

\footnotetext{
${ }^{24}$ Eko Jauhari,wawancara, selaku kepala Kantor Badan Pertanahan Kabupaten Tulungagung pada tanggal 04 Januari 2020 .

25 Ibid.
} 
6. Faktor Ekonomi, tidak bida disangkal lagi dengan adanya perkembangan masyarakat yang sangat pesat, hal ini juga seiring sejalan dengan kebutuhan masyrakat yang semakin meningkat tidak hanya dengan hidup sederhana sepeerti dulu, hal ini menjadi salah kaprah karena dari faktor kurangnya ekonomi menjadikan tanah yang menghasilkan satu-satunya dijual untuk memenuhi kebutuhan yang singkat bahkan untuk hidup mewah sesaat, hal ini banyak ditemukan di desa jabalsari, beberapa petani mengaku memenuhi kebutuhan keluarga contoh kecil kebutuhan pendidikan anak yang tidak memakan biaya yang tidak sedikit, situasi ini juga dimanfaatkan oleh calon pembeli dengan membeli tanah tersebut dengan harga yang tidak terlalu mahal untuk menambah investasi untuk kedepan.

Fakta di lapangan tanah-tanah pertanian yang seharusnya menjadi sumber utama penghasilan petani khususnya di desa Jabalsari sebagian besar hampir 20 persen beralih haknya kepada orang yang tinggal diluar kecamatan sumbergempol, walaupun sadar dengan berpindah hak tanah pertanian kepada orang lain akan memutus tali penghasilan yang utama bagi petani setempat namun juga hal ini juga tidak bisa membendung derasnya kebutuhan petani sebagai masyarakat pada umumnya dan juga beberapa mengaku gagal panen sehingga tidak dapat lagi mempertahankan tanahnya, dan dibarengi tidak tunya petani akan peraturan bahwa tanah pertanian yang dimiliki secara absentee tidak diperkenankan alias dilarang secara tegas. Beberapa tanah yang sudah dijual bahkan beralih fungsi dan tidak lagi berproduktivitas selayaknya tanah pertanian yang lainnya.

Dalam konteks pembangunan, pemerintah juga membagi beberapa zona atau tata ruang yang salah satunya adalah zona pertanian atau tanah sawah hal ini juga disesuaikan dengan keadaan desa dan profesi sebagian besar masyarakat desa tersebut,tidak mungkin pemerintah tidak menyediakan lahan hijau atau zona pertanian untuk mendukung profesi masyarakat dan mensejahterakan masyarakat setempat dan juga berdikari mandiri untuk kebutuhan pangan daerah setempat dan membantu perputaran ekonomi daerah.

Pada kondisi-kondisi tertentu bahwa banyak tanah yang dikuasai oleh berbagai pihak dari berbagai kalangan, hal ini saangat bertolak belakang dengan aturan yang berlaku, hal ini menjadi pekerjaan rumah bagi pemerintah setempat untuk merubahnya supaya tidak adanya ketimpangan tata ruang karena tanah dan tata ruang adalah satu bagian yang tidak bisa terpisahkan satu sama lain. Banyak faktor yang menentukan tata ruang berawal dari kondisi tanah, lokasi tanah, kontur tanah dan iklim cuaca yang ada di derah tanah tersebut berada.

Dasar kebijaksanaan pertanahan adalah pasal 33 ayat (3) UUD 1945 yang dijabarkan lebih lanjut dalam UU No 5 tahun 1960 (UUPA). Pada pasal 2 ayat (1) UUPA ditegaskan lagi bahwa bumi, air dan ruang angkasa, termasuk kekayaan alam yang terkandung didalamnya dikuasai oleh negara sebagai organisasi kekuasaan seluruh rakyat.

Kebijakan pemerintah sangat strategis untuk menata ruang agraris atau lahan pertanian, biasanya kawasan ditentukan lahan pertanian atau kawasan agraris banyak terdapat di pedesaan, hal ini menyesuaikanm pada profesi masyarakat setempat dan akan mendorong ekonomi mikro. Hal ini juga sangat berpengaruh pada ketahanan pangan yang di daulat dimuali dari pedesaan hingga berimbas ke kota, dengan strategi ini ketahanan pangan nasional akan stabil dan sedikit demi sedikit akan meingkat, 
namun penataan ruang dalam hal pertanian belum berasa optimal karena adanya beberapa daerah yang masih belum bisa memaksimalkan sumber daya yang ada. Terkadang tata ruang ini hanyalah peta buta yang tidak dilaksankan sama sekali dalam penataan yang real di lapangan, sehingga tidak efektif sama sekali dan tidak direalisasikan.

Dalam hal penataan ruang biasanya terdapat bentrok atau benturan antara sektor yang paling dirasakan pemekaram daerah kota misalnya, secara otomatis beberapa lahan pertanian akan digusur dan akan dijadikan lahan untuk tempat tinggal, disamping itu pertumbuhan masyarakat sangat pesat sehingga semakin luas lahan untuk dimanfaatkan sebagai sarana untuk kehidupan. Dalam tata ruang juga masih banyak tarik ulur kebijakan atau inkonsistensi dan sangatlah tidak tegas, bahkan ada beberapa wilayah dibangun atau dimanfaatkan tidak sesuai dengan tata ruang yang sudah diatur oleh pemerintah. Padahal keseimbangan antar sektor sangatlah penting untuk mendukung satu sama lain, khususnya sektor pertanian merupakan leading sektor dalam menunjang ketahanan pangan nasional.

Ketidak selarasan pemanfaatan ruang antara manusia dengan alam untuk mewujudkan kegiatan manusia dan prekonomian semata juga berdampak sangat buruk apabila tidak terkontrol bahkan sampai bisa menimbulkan kerugian yang sangat besar karena tidak memperhatikan kelestarian lingkungan, salah satu contoh pembiaran pelestarian akan menyebabkan bencana alam seperti banjir dan tanah longsor. Hal ini karema kurangnya lahan-lahan yang dimanfaatkan sebagai pencegah bencana yakni lahan penghijaun penyerapan air.

Semua perbuatan manusia yang menyebabkan hal diatas terjadi karena belum bisa menahan masing-masing keinginannya yang kadang terlalu berlebihan ingin menguasai banyak sektor dan lahan, menyebabkan juga tidak seimbangnya kemampuan ekonomi, bahkan beberapa masyarakat rela mengesampingkan hukum untuk memenuhi kebutuhan mereka masing-masing

Larangan pemilikan tanah pertanian secara absentee walaupun sudah diatur dalam “Peraturan Pemerintah Nomor 224 Tahun 1961 yang dirubah dengan Peraturan Pemerintah Nomor 41 Tahun 1964 tentang Pelaksanaan Pembagian Tanah dan Pemberian Ganti Rugi dan ditegaskan kembali dalam Peraturan Menteri Agraria Dan Tata Ruang/ Kepala Badan Pertanahan Nasional Nomor 18 Tahun 2016 Tentang Pengendalian Penguasaan Tanah Pertanian", sesuai data yang diambil di lapangan masih banyak pemilikan hak atas tanah pertanian secara absentee berada di desa Jabalsari kecamatan Sumbergemol, hal ini juga tidak dibendung oleh badan pertanahan nasional kabupaten Tulungagung dan sejauh ini belum bisa mengefektifitaskan peraturan yang ada masalah kepemilikan tanah pertanahan secara absentee. Sejauh ini menurut keterangan yang diambil dari kepala kantor Badan Pertanahan Nasional Kabupaten Tulungagung bapak Eko Jauhari menyatakan bahwa tindakn satu-satunya yang bisa dilakukan untuk mencegah pemilikan tanah pertanian secara absentee hanyalah melalui pengecekan kartu tanda penduduk calon pembeli, apabila calon pembeli berasal dari luar daerah jual beli akan ditolak dan tidak dapat dilangsungkan, sejauh ini tidak ada pendataan lebih jauh dan lebih mendetail masalah tanah pertanian.

Ketentuan tersebut sesuai dengan ketentuan yang terdapat pada Pasal 6 ayat (1) Peraturan Meteri Negara Agraria/ Kepala Badan Pertanahan Nasional Nomor 9 Tahun 1999 Tentang Tata Cara Pemberian Dan Pembatalan Hak Atas Tanah Negara Dan Hak Pengelolaan, yang menyebutkan "Keputusan pembatalan hak atas tanah karena cacad hukum administratif dalam penerbitannya, dapat dilakukan karena permohonan yang 
berkepentingan atau oleh Pejabat yang berwenang tanpa permohonan." 26 "Cacad hukum administratif yang disebutkan dalam Pasal 106 ayat (1) antara lain":

a. "Kesalahan prosedur;

b. Kesalahan penerapan peraturan perundang-undangan;

c. Kesalahan subjek hak;

d. Kesalahan objek hak;

e. Kesalahan jenis hak;

f. Kesalahan perhitungan luas;

g. Terdapat tumpang tindis hak atas tanah;

h. Data yuridis atau data fisik tidak benar; atau

i. Kesalahan lainnya yang bersifat hukun administratif" .27

Penyelesaian masalah pertanahan merupakan kewajiban yang harus dilaksanakan oleh Badan Pertanahan nasional karena telah diberikan kewenangan oleh pemerintah melalui Pertauran Pemerintah Nomor 20 tahun 2015 tentang Badan Pertanahan Nasional dan kemudian dijabarkan dalam Peraturan Kepala Badan Pertanahan Nasional Republik Indonesia Nomor 3 Tahun 2011 tentang Pengelolaan Pengkajian Dan Penagganan Kasus Pertanahan. dalam hal pertanggung jawaban daerah setempat yang mempunyai wewenang menegakkan aturan tentang tanah pertani secara absentee adalah Kantor Pertanahan Kabupaten Tulungagung dan hal ini tentu saja perpanjangan wewenang yang dimiliki oleh Kantor Badan pertanahan Nasional atau pusat mengacu pada "Pasal 2 ayat (1b) Peraturan Kepala Badan Pertanahan Nasional Nomor 3 Tahun 2011 tentang Pengelolaan Pengkajian Dan Penagganan Kasus Pertanahan" yang menyatakan Badan Pertanahan harus "Meyelesaikan kasus pertanahan yang disampaikan kepada kepala Badan Pertanahan Nasional agar tanah dapat dikuasai, dimiliki, dipergunakan dan dimanfaatkan oleh pemiliknya serta dalam rangka kepastian dan perlindungan hukum".28

Badan pertanahan Nasional juga bertanggung jawab atas segala persoalan menganai tanah dan tentu juga mengenai pemilikan tanah Pertanian Absentee yang telah dimiliki oleh orang diluar Wilayah Kecamatan letak tanah itu berada. Kantor Pertanahan Kabupaten Tulungagung juga sudah melakikan beberapa upaya salah satunya memberikan surat perintah terhadap camat masing-masing daerah sebagai PPAT sementara untuk langsung terjun memberikan sosialisasi, hal ini juga bekerja sama dengan IPPAT kabupaten Tulungagung, untuk menghimbau secara tidak langsung bahwa client yang akan meperjual belikan tanah pertanian akan diberikan penyuluhan dan pemahaman hukum yang baik, untuk memperhatikan ketentuan pemilikan tanah

${ }^{26}$ Pasal 6 ayat (1), Peraturan Menteri Negara Agraria/ Kepala Badan Pertanahan Nasional Nomor 9 tahun 1999 tentang Tata Cara Pemberian Dan Pembatalan Hak Atas Tanah Negara Dan Hak Pengelolaan.

27 Pasal 107, Peraturan Menteri Negara Agraria/Kepala Badan Pertanahan Nasional Nomor 9 Tahun 1999 tentang Tata Cara Pemberian Dan Pembatalan Hak Atas Tanah Negara Dan Hak Pengelolaan.

${ }_{28}$ Pasal 2 ayat (1b), Peraturan Kepala Badan Pertanahan Nasional Nomor 3 Tahun 2011 tentang Pengelolaan Pengkajian Dan Penanggungan Kasus Pertanahan. 
secara Absentee dalam pembuatan permohonan pemindahan hak yang pemegang haknya berstatus absentee atau mengakibatkan pemegang hak-nya menjadi pemegang hak yang absentee.

Bapak Eko Jauhari juga berharap adanya suatu alat yang dapat mendeteksi secara terus menerus mengenai pemilikan tanah diseluruh Indonesia, misalnya bisa bekerja sama dengan Kantor Catatan Sipil untuk dapat mengetahui domisili pemilik tanah dengan cepat dan tepat, serta dapat diakses dan terkoneksi dengan seluruh Kantor Pertanahan seluruh Indonesia. Tidak hanya itu, dia juga mengatakan bahwa tertib permasalah pemilikan tanah ini tidak akan terselesaikan apabila tidak ada kerjasama dari masyarakat untuk memberitahukan/ melaporkan tentang adanya pemilik tanah yang berstatus absentee.

Berdasarkan hasil Penelitian di Lapangan, penerapan ini belum bisa diterapkan dengan tegas kepada pemilik tanah pertanian secara absentee karena terdapat berbagai hambatan yang terjadi dilapangan, meskipun peraturannya sudah sangatlah jelas. Sehingga penegakan terhadap larangan pemilikan tanah pertanian secara absentee tidak tegas. Dengan keadaan saat ini saksi yang diberikan sudah tidak relevan lagi karena di anggap terlalu ringan sehingga cenderung mudah dilanggar, hal ini disebabkan pembuatan Peraturannya belum menyesuaikan keadaan pada saat itu dan sangatlah berbeda jauh dengan keadaan saat ini dan meskipun sudah dikeluarkan Peraturan Kepala Badan Pertanahan Nasional Nomor 3 Tahun 2011 tentang Pengelolaan Pengkajian Dan Penagganan Kasus Pertanahan sebagai penegasan dari peraturan sebelumnya, namun ketentuan ini tidak memberikan sanksi hukum bagi pemilik tanah Absentee yang seharusnyadisesuaikan dengan keadaan saat ini, melainkan penerapan sanksi hukumannya masih mengikuti penerapan peraturan yang lama.

\section{Kesimpulan}

Kepemilikan tanah pertanian secara absentee ternyata belum dapat dilaksanakan secara efektif khususnya di Desa Jabalsari Kecamatan Sumbergempol Kabupaten Tulungagung. Semua pengaturan yang ada pada bahasan tersebut diatas belum efektif dibuktikkan dengan penelitian di lapangan masih banyak adanya kepemilikan tanah pertanian diluar penduduk sekitar khsususnya di Desa Jabalsari Kecamatan Sumbergempol Kabupaten Tulungagung, Penerapan kepemilikan tanah absentee dianggap banyak terhambat secara teknis di lapangan karena masih adanya masyarakat yang kurang sadar hukum karena beberapa masyarakat menganggap peraturan itu tidak ada bahkan sebagian besar masyarkat tidak tau adanya aturan tersebut diatas dan memang karena nilai tanah itu sendiri semakin tahun akan semakin sangat tinggi, masyarkat tergiur untuk menjual dengan cara apapun dan masih banyak faktor-faktor yang mendukung kegiatan ini berlangsung.

\section{Saran}

Pemerintah dalam hal ini yang berhubungan dengan peralihan hak milik atas tanah yakni Badan Pertanahan Nasional dan PPAT/PPAT sementara (camat) supaya dalam pemberian hak penguasaan dalam peralhan hak atas tanah pertanian tida cacad hukum secara prosedur, objek dan subjek yang diberikan, dan bahkan kesalahan penerapan peraturan perundang-undangan atau kesalahan lainnya bersifat administrative dan Penyuluhan hukum dan sosiali sasi secara rutin oleh aparat yang bersangkutan adalah salah satu cara sebagai pendekatan langsung kepada masyarakat demi terciptanya tertib hukum dan demi perbaikan permasalahan kepemilikan tanah 
secara absentee, dalam hal ini peran pemerintah sangatlah penting demi terciptanya kepastian hukum dan hukum yang tidak cacad secara administratif.

\section{Daftar Pustaka / Daftar Referensi}

Buku/Literatur

Bambang Suggono. (1997). Metode Penelitian Hukum. Jakarta : Rajawali Pers.

Boedi Harsono. (2015). Hukum Agraria Indonesia, Sejarah Pembentukan Undang-Undang Pokok Agraria, Isi dan Pelaksanaanya. Jakarta : Djambatan.

Echols, Jhon M dan Hassain Sadhily. (2012) Kamus Inggris-Indonesia (an EnglishIndonesian Dictionary). Jakarta: Gramedia.

Ef fendi Perangin. (1986) Hukum Agraria di Indonesia, Suatu Telaah dari Sudut Pandang Praktisi Huku. Jakarta : Rajawali.

\section{Jurnal}

Abdurahman, Sultan, "Tinjauan Yuridis Kepemilikan Tanah Absentee Dikaji dari Undang-undang Nomor 5 Tahun 1960 Tentang Peraturan Dasar Pokok Agraria", Lex Crimen, vol. 5, no. 6, 2016.

Ardiansyah Al Ghani, "Kebijakan Penyelesaian Tanah "Absentee/Guntai" Di Kabupaten Boyolali Berdasarkan Undang-Undang Nomor 56 PRP Tahun 1960 Tentang Penetapan Luas Tanah Pertanian", Repertorium Jurnal Pemikiran E Penelitian Bidang Keperdataan dan Kenotariatan Kenotariatan, Vol. 5, No. 1, 2018.

Dinalara Dermawati Butarbutar, "Mengatasi Kepemilikan Tanah Absentee/Guntai". Pakuan Law Review, Vol. 1, No. 2, 2015.

Chandra Dewangga Marditya Putra, "Penerapan Larangan Pemilikan Tanah Pertanian Secara Absentee", Jurnal Hukum \& Kenotariatan, Vol. 3, No. 2, 2019.

Elfira Permatasari, Habib Adjie dan Hardianto Djanggih, "Perlindungan Hukum Kepemilikan Tanah Absentee yang diperoleh Akibat Pewarisan", Varia Justicia, Vol. 14, No. 1, 2018.

\section{$\underline{\text { Peraturan Perundang-Undangan }}$}

Undang-Undang Nomor 5 Tahun 1960 tentang Peraturan Dasar Pokok-pokok Agraria.

Peraturan Menteri Negara Agraria/ Kepala Badan Pertanahan Nasional Nomor 9 tahun 1999 tentang Tata Cara Pemberian Dan Pembatalan Hak Atas Tanah Negara Dan Hak Pengelolaan.

Peraturan Menteri Negara Agraria/Kepala Badan Pertanahan Nasional Nomor 9 Tahun 1999 tentang Tata Cara Pemberian Dan Pembatalan Hak Atas Tanah Negara Dan Hak Pengelolaan.

Peraturan Menteri Agraria dan tata ruang/Kepala Badan Pertanahan Nasional Nomor 18 Tahun 2016 tentang Pengendalian Penguasaan Tanag Pertanian.

Peraturan Menteri Agraria Dan Tata Ruang/ Kepala Badan Pertanahan Nasional Nomor 18 Tahun 2016 tentang Pengendalian Penguasaan Tanah Pertanian.

Peraturan Pemerintah Nomor 224 Tahun 1961 tentang Pelaksanaan Pembagian Tanah dan Pemberian ganti Kerugian.

Peraturan Kepala Badan Pertanahan Nasional Nomor 3 Tahun 2011 tentang Pengelolaan Pengkajian Dan Penanggungan Kasus Pertanahan. 


\section{Wawancara}

Eko Jauhari, Wawancara, selaku kepala Kantor Badan Pertanahan Kabupaten Tulungagung.

Jamal, Wawancara, selaku Petani Penggarap tanah Absentee di desa Jabalsari

Mahmudi, Wawancara, selaku kepala desa Jabalsari Kabupaten Tulungagung.

Selamet, Wawancara, pemilik tanah pertanian absentee di Desa Jabalsari kabupaten Tulunggagung. 